\title{
NILAI TAKSONOMI CIRI MORFOLOGI TUMBUHAN BERDAUN SAPUTANGAN DALAM CAESALPINIACEAE
}

\author{
Etha Marista ${ }^{1}$ \& Alex Hartana ${ }^{2}$ \\ ${ }^{1}$ Program Studi Biologi Tumbuhan, Sekolah Pascasarjana Institut Pertanian Bogor. Kampus Dramaga, Bogor \\ 16680. Email: ethamarista@gmail.com \\ ${ }^{2}$ Departemen Biologi, Fakultas Matematika dan Ilmu Pengetahuan Alam, Institut Pertanian Bogor, Kampus \\ Dramaga, Bogor 16680. \\ Korespondensi: ahartana301249@gmail.com
}

Etha Marista \& Alex Hartana. 2019. Taxonomic Value of Morphological Characters in Handkerchief Leaved Caesalpiniaceae. Floribunda 6(3): 103-115. - Young leaf specimens of plants were rarely found in herbarium collections, thus their taxonomic values to recognize species diversity never been studied. Caesalpiniaceae is a plant family which has genera with leaf flushing characteristics known as "handkerchief leaved-plant". For this purpose, living specimens of sixteen species of Caesalpiniaceae with handkerchief leaves were observed. The results showed that sixteen species belonging to five genera can be distinguished based on the morphological characteristics of leaf flushing, namely the presence of perules, the form of dormant leaf buds and developing leaf buds, the color of leaf during flushing, the type of growing leaf bud indumentum, shape variations of leave during the flushing process, the number and size of the leaves. An identification key to five genera and their species was constructed based on the characteristics of leaf flushing.

Keywords: Diagnostic importance, leaf flushing, specific character.

Etha Marista \& Alex Hartana. 2019. Nilai Taksonomi Ciri Morfologi Tumbuhan Berdaun Saputangan dalam Caesalpiniaceae. Floribunda 6(3): 103-115 - Spesimen daun muda tumbuhan umumnya jarang ditemukan pada koleksi herbarium sehingga tidak pernah diteliti nilai taksonominya sebagai pengenal keanekaragaman jenis. Caesalpiniaceae merupakan suku tumbuhan yang beberapa marganya memiliki karakteristik pemoposan daun (leafflushing) yang dikenal dengan sebutan"daun saputangan". Untuk itu, enam belas jenis dari suku Caesalpiniaceae berdaun saputangan diamati spesimen hidupnya. Hasil penelitian menunjukkan bahwa enam belas jenis yang tergolong dalam lima marga Caesalpiniaceae berdaun saputangan dapat dibedakan berdasarkan ciri morfologi pemoposan daunnya seperti: keberadaan perula, bentuk kuncup daun dorman, dan kuncup daun tumbuh, warna daun saat pemoposan, tipe indumentum kuncup daun tumbuh, variasi bentuk daun selama proses pemoposan, jumlah dan ukuran daun. Kunci identifikasi lima marga beserta jenis-jenisnya disediakan berdasarkan ciri pemoposan daun tersebut.

Kata kunci: Kepentingan diagnosis, pemoposan daun, penciri jenis.

Di lembaga-lembaga herbarium umumnya belum ditemukan koleksi spesimen daun muda tumbuhan, sehingga daun muda belum pernah diteliti nilai taksonominya untuk mengenal keanekaragaman jenis. Sebagai akibatnya, kunci identifikasi berdasarkan karakter daun muda belum banyak dilaporkan. Padahal, beberapa jenis tumbuhan memiliki karakteristik pemoposan daun (leaf flushing). Pemoposan daun merupakan salah satu bagian dari perkembangan vegetatif tumbuhan yang ditandai dengan proses keluarnya daun muda secara mengelompok sekaligus. Karakter warna daun muda kumungkinan dapat digunakan sebagai karakter potensial dalam mengidentifikasi jenis tumbuhan, walaupun tidak dapat digunakan secara umum karena karakter ini tidak dapat diamati pada spesimen herbarium (Balgooy 1997).

Penelitian yang dilakukan oleh Putri \& Chikmawati (2015) pada marga Diospyros menunjukkan bahwa ciri pemoposan daun dapat digunakan untuk membedakan delapan jenis Diospyros. Ciri yang digunakan antara lain adalah warna kuncup, keberadaan dan tipe indumentum pada kuncup, pola set pemoposan daun, panjang kuncup, tipe pelipatan daun, bentuk daun muda, jumlah katafil yang terlihat saat kuncup dorman membuka.

Caesalpiniaceae merupakan suku tumbuhan yang beberapa marganya memiliki karakteristik pemoposan daun yang menghasilkan dedaunan sangat khas, yang dikenal dengan sebutan tumbuhan "daun saputangan". Marga-marga Caesal- 
piniaceae yang termasuk dalam kelompok berdaun saputangan antara lain adalah Amherstia, Brownea, Cynometra, Maniltoa, dan Saraca (Budiman 1978). Kelompok tumbuhan ini banyak dimanfaatkan sebagai tanaman hias dan juga peneduh jalan (Uji 1980).

Daun muda tumbuhan berdaun saputangan dalam suku Caesalpiniaceae terbentuk karena adanya pengaruh proses fenologi dan perkembangan struktur kuncup daun muda yang memiliki perula yang kemudian tampak mengering serta menghasilkan 1-9 ruas dalam sekali pemoposan daun. Pada mulanya ujung ranting tempat daun muda yang keluar dari kuncup bersifat sangat lunak dan lemas sehingga terlihat menggantung. Daun muda yang muncul berwarna putih, atau merah muda pucat, atau hijau muda lalu berangsur-angsur menjadi hijau (Backer \& Bakhuizen van den Brink 1965). Proses pemoposan tersebut tidak terjadi secara terus menerus sepanjang tahun, tetapi hanya pada waktu-waktu tertentu (Rahmania \& Munandar 2005). Umumnya kelompok daun muda muncul di ujung ranting dan tampak bergelayutan mirip helaian sekelompok saputangan yang diikat bersama pada salah satu bagian ujungnya. Bersamaan dengan muncul, berkembang dan menjadi sempurnanya daun muda, secara bertahap ujung ranting menjadi kaku dan tumbuh lurus sehingga akibatnya setelah dewasa struktur saputangan yang menggantung jadi menghilang.

Struktur daun saputangan pada kelompok tumbuhan Caesalpiniaceae berdaun saputangan belum pernah diteliti nilai taksonominya sebagai pembeda jenis, maka penelitian ini bertujuan untuk mengenal jenis-jenis dalam kelompok suku tersebut berdasarkan ciri pemoposan daun serta mencari makna kegunaan pemoposan daun sebagai ciri diagnostik pembeda jenis.

\section{METODE PENELITIAN}

Bahan tumbuhan yang digunakan dalam penelitian ini berupa 16 jenis (5 marga) tumbuhan berdaun saputangan suku Caesalpiniaceae dari marga Amherstia (A. nobilis Wall.), Brownea (B. ariza Benth., $B$. capitella Jacq., $B$. grandiceps Jacq., B. racemosa Jacq.), Cynometra (C. cauliflora L., C. mannii Oliv., C. minutiflora F. Muell., C. ramiflora L.), Maniltoa (M. grandiflora Scheff., M. lenticellata C.T. White., M. plurijuga Merr. \& L.M. Perry., M. polyandra (Roxb.) Harms., $M$. schefferi K. Schumann), dan marga Saraca (S. indica L., S. thaipingensis Prain), yang berada di Kebun Raya Bogor (KRB), Herbarium Bogoriense
(BO) LIPI Cibinong, dan lingkungan sekitar Kampus IPB Dramaga.

Pengamatan dilakukan di lapangan tempat tumbuhnya jenis tersebut dan di Laboratorium Ekologi dan Sumber Daya Tumbuhan, Departemen Biologi Fakultas MIPA, IPB. Pengamatan terhadap variasi ciri morfologi vegetatif meliputi kuncup daun dorman (keberadaan perula, bentuk, ukuran, warna), kuncup daun tumbuh (bentuk, ukuran, warna, tipe indumentum, tipe pelipatan daun dalam kuncup, lama waktu terbukanya kuncup yang diukur dari awal pengamatan), daun saputangan muncul (warna, tipe penggulungan daun dalam kuncup), daun saputangan terlipat (jumlah bekas perula, bentuk ruas, ukuran ruas, warna ruas, bentuk helaian anak daun, ukuran helaian anak daun, warna helaian anak daun, pangkal helaian anak daun, tepi helaian anak daun, ujung helaian anak daun, ukuran tangkai daun, warna tangkai daun, jumlah tangkai daun, tipe indumentum tangkai daun, warna indumentum tangkai daun, jumlah tangkai helaian anak daun, jumlah daun, jumlah daun dalam satu tangkai, simetri helaian anak daun, keberadaan daun penumpu, bentuk daun penumpu, ukuran daun penumpu, ukuran rambut-rambut keras (bristle), dan daun saputangan terbuka (warna) (Hickey 1973; Cullen 1978; Radford 1986; Bell 1991; Ash et al. 1999; Harris \& Harris 2001). Kuncup daun pada cabang atau ranting yang diamati ditandai dengan menggunakan label pada hari pertama pengamatan, dan diamati perkembangannya secara berkala ketika terbentuknya daun muda sampai menjadi dewasa. Setiap jenis dibuatkan voucer spesimen yang diawetkan sebagai herbarium, dan disimpan di Herbarium Bogoriense (BO). Istilah biologi yang digunakan dalam penelitian ini mengikuti Rifai \& Puryadi (2008).

Semua spesimen daun saputangan difoto menggunakan kamera Nikon Coolpix S9900, sedangkan ciri morfologi lain seperti kuncup dorman, tipe dan warna indumentum pada kuncup dorman serta tangkai daun diamati menggunakan mikroskop stereo Olympus SZ61 kemudian didokumentasikan dengan Optilab ${ }^{\circledR}$ Viewer versi v2.1. Ciri morfologi yang diamati dianalisis kemiripan dan perbedaannya dan ditabulasi.

\section{HASIL DAN PEMBAHASAN}

\section{Pengamatan Maniltoa grandiflora sebagai Tumbuhan Model}

Perkembangan pemoposan daun saputangan Maniltoa grandiflora dijadikan sebagai model un- 
tuk pengamatan kelompok jenis berdaun saputangan, karena jenis ini paling umum dijumpai dan sering menghasilkan daun muda, memiliki perula yang lebih banyak dalam satu kali pemoposan daun, serta memunyai waktu pemoposan daun lebih lama jika dibandingkan dengan jenis-jenis pada marga lainnya.

Fase kuncup ditandai dari munculnya bakal daun yang berupa sisik kuncup yang disebut dengan istilah perula. Perula tersebut akan meninggalkan bekas garis jika luruh. Pada kelompok suku Caesalpiniaceae berdaun saputangan ini memiliki perula, berbeda dengan hasil penelitian Nicolini et al. (2012) pada marga Diospyros, yang memiliki katafil. Katafil ini juga berupa sisik-sisik kuncup tetapi meninggalkan lubang atau cekungan besar jika luruh. Kuncup dorman mengerucut, berukuran panjang 1.5-2 mm, serta memiliki indumentum bertipe meroma berwarna cokelat. Saat tumbuh atau mulai mekar, kuncup $M$. grandiflora melanset dan berwarna putih kecokelatan. Memasuki fase kuncup daun, tumbuh, warna perula berubah menjadi pudar kecokelatan kemudian mengering. Bentuk perula memanjang, berukuran antara 1-14 $\mathrm{cm}$, jumlah perula dalam satu kuncup mencapai 18-20 helaian. Vernasi kuncup bertipe ekuitan.

Fase daun saputangan muncul ditandai dengan munculnya daun muda yang melipat sampai lipatan daun mulai membuka seluruhnya. Pelipatan daun $M$. grandiflora bertipe tergulung masuk (involute). Daun muda yang tertutup seluruhnya memiliki warna putih hingga merah jambu pucat. Saat memasuki fase daun saputangan terlipat, terjadi perubahan warna pada tangkai daun, helaian daun, dan indumentum pada tangkai daun. Warna daun pada M. grandiflora yaitu merah jambu pucat yang semula berwarna putih kekuningan, tangkai daun berwarna hijau, indumentum berwarna cokelat. Daun saputangan terbuka pada $M$. grandiflora ditandai dengan perubahan warna daun muda menjadi hijau muda. Pada fase ini, tidak ditemukan perubahan morfologi lebih lanjut.

\section{Variasi Fase Kuncup Daun Dorman}

Kuncup daun dorman adalah masa periode pertumbuhan yang konstan, tidak ada perubahan morfologi lagi. Pada tumbuhan berdaun saputangan memiliki variasi kuncup daun dorman yaitu bentuk mengerucut yang dapat dilihat pada jenis memiliki bentuk kerucut $M$. grandiflora dan $M$. lenticellata, membundar pada jenis $M$. plurijuga, M. polyandra, M. schefferi, C. mannii, C. ramiflora, dan membulat telur ditemukan pada jenis $B$. ariza, B. capitella, B. grandiceps, B. racemosa, $C$. cauliflora, C. minutiflora (Gambar 1). Variasi warna pada kuncup dorman terdiri dari dua varisi warna yaitu hijau dan cokelat.

Ukuran panjang kuncup daun dorman bervariasi mulai dari $1.2 \mathrm{~mm}$ (M. lenticellata), sampai $2.7 \mathrm{~mm}$ (B. racemosa). Kisaran panjang kuncup daun dorman jenis-jenis Brownea lebih panjang (1.5-2.7 $\mathrm{mm})$ dibandingkan panjang kuncup daun dorman dengan marga Cynometra (1-2 $\mathrm{mm})$ dan Maniltoa $(1.2-2 \mathrm{~mm})$

Tidak semua jenis dalam suku Caesalpiniaceae berdaun saputangan memiliki fase kuncup daun dorman yang jelas teramati meskipun pengamatannya dilakukan dalam waktu lama, seperti pada marga Amherstia dan marga Saraca. Kuncup daun dorman pada dua marga ini tidak tampak karena kuncup daunnya tidak memiliki perula.

\section{Variasi Fase Kuncup Daun Tumbuh}

Memasuki fase kuncup tumbuh setelah fase dorman terlewati, dimana perula mulai jelas terlihat, warna perula cokelat pucat kemudian mengering. Kuncup daun tumbuh bervariasi, terdiri atas variasi bentuk dan panjang kuncup daun tumbuh, tipe pelipatan daun dalam kuncup, tipe dan warna indumentum, serta lama waktu terbukanya kuncup. Kuncup daun tumbuh pada jenisjenis tumbuhan berdaun saputangan memiliki 5 variasi bentuk, yaitu melanset yang ditemukan pada jenis $M$. grandiflora, $S$. indica, dan $S$. thaipingensis, bentuk melanset bagian tengah agak melebar ditemukan pada $M$. polyandra, melanset pendek pada semua jenis Cynometra yang diamati, melonjong ujung runcing ditemukan pada $M$. schefferi, melonjong ditemukan pada jenis $M$. lenticellata, M. plurijuga dan A. nobilis, serta melancor ditemukan pada semua jenis Brownea yang diamati (Gambar 2).

Panjang kuncup daun tumbuh pada tumbuhan berdaun saputangan mewakili setiap marga. Ciri ini hanya digunakan untuk mengelompokkan jenis-jenis tumbuhan berdaun saputangan ke dalam kelompok marganya, tidak spesifik menunjukkan perbedaan jenis. Marga Maniltoa rata-rata 0.5-12 $\mathrm{cm}$, pada marga Brownea rata-rata $0.4-17 \mathrm{~cm}$, sedangkan pada Cynometra rata-rata $0.4-1.5 \mathrm{~cm}$.

Tipe indumentum kuncup daun tumbuh bervariasi pada lima marga, antara lain meroma (pilose) (semua jenis Maniltoa), berbulu balig (pubescent) (semua jenis Brownea), berbulu sikat (hispid) (semua jenis Cynometra), memisai (hirsute) (semua jenis Saraca), dan mengewol (lanate) (A. nobilis).Ciri tipe indumentum pada 
kuncup daun tumbuh belum bisa digunakan sebagai ciri untuk membedakan tumbuhan berdaun saputangan sampai tingkatan jenis.

Tipe pelipatan daun pada kuncup tumbuh pada jenis-jenis berdaun saputangan memiliki dua variasi yaitu ekuitan dan melingkar. Jenis-jenis dari marga Amherstia, Brownea, Cynometra, dan Maniltoa memiliki vernasi daun bertipe ekuitan, sedangkan jenis-jenis-jenis Saraca bertipe melingkar.

Variasi bentuk dan warna kuncup daun tumbuh pada tumbuhan berdaun saputangan merupakan ciri yang baik untuk digunakan sebagai ciri diagnostik untuk mengelompokkan berdasarkan jenisnya. Variasi ciri lain pada kuncup daun tumbuh dalam penelitian ini terdapat pada vernasinya yaitu tipe ekuitan dan melingkar hanya bisa mengelompokkan sampai tingkat marga saja.

\section{Variasi Fase Daun Saputangan Muncul}

Fase daun saputangan muncul merupakan fase yang terjadi setelah kuncup daun tumbuh dan menandai awal dari proses pemoposan daun. Variasi morfologi daun saputangan muncul meliputi tipe penggulungan daun dalam kuncup, warna daun muda, tipe indumentum tangkai daun, warna tangkai daun muda, dan warna indumentum pada tangkai daun muda. Tipe penggulungan daun bervariasi: tergulung masuk (involute) pada jenis Maniltoa, daun terlipat sekali secara adaksial atau ke dalam sepanjang ibu tulang (conduplicate) pada jenis-jenis Saraca dan Amherstia nobilis, menggulung-gulung sampai tergulung masuk (supervolute-involute) pada jenis-jenis Brownea, dan menggulung-gulung (supervolute) pada jenis-jenis Cynometra.

Jenis-jenis marga Maniltoa memiliki warna daun muda yang bervariasi mulai dari putih kekuningan-merah jambu pucat ( $M$. grandiflora), merah jambu (M. lenticellata), putih kehijauan $(M$. plurijuga), hijau muda dengan bagian tepinya berwarna merah jambu (M. polyandra), dan merah jambu muda (M. schefferi). Daun muda pada semua jenis Brownea berwarna ungu tua bercorak hijau, sedangkan pada marga Cynometra berwarna merah keunguan $(C$. cauliflora dan $C$. mannii), merah kecokelatan (C. minutiflora), dan putih dengan bagian tepi merah jambu (C. ramiflora). Pada marga Saraca ditemukan dua variasi warna daun muda merah marun keunguan ( $S$. indica) dan ungu tua kecokelatan (S. thaipingensis), sedangkan daun muda $A$. nobilis berwarna cokelat muda (Gambar 3).

\section{Variasi Fase Daun Saputangan Terlipat}

Pada variasi daun saputangan terlipat, ciri yang baik untuk digunakan sebagai ciri diagnostik dalam mengelompokkan hingga tingkatan jenis adalah bentuk, warna daun, dan warna tangkai daun. Ciri lain seperti tipe indumentum pada tangkai daun hanya dapat digunakan untuk mengelompokkan pada tingkatan marga.

Daun saputangan terlipat merupakan fase yang terjadi setelah proses daun saputangan muncul telah berakhir. Fase ini masih kelanjutan dari proses pemoposan daun yang ditandai dengan perula yang sudah mulai luruh. Morfologi fase daun saputangan terlipat meliputi tipe indumentum tangkai daun, warna indumentum tangkai daun, warna daun, dan warna tangkai daun. Variasi tipe indumentum tangkai daun muda meroma (pilose) ditemukan pada jenis-jenis Maniltoa yang diamati. Tipe indumentum mengewol (lanate) dijumpai pada $A$. nobilis, tipe indumentum berbulu balig (pubescent) ditunjukkan oleh jenis-jenis dari marga Brownea yang diamati. Tipe indumentum berbulu sikat (hispid) ditemukan pada semua jenis dari marga Cynometra yang diamati, sedangkan tipe indumentum memisai (hirsute) ditemukan pada dua jenis dari marga Saraca yang diamati (Gambar $4)$.

Warna indumentum tangkai daun cokelat ditemukan pada jenis-jenis Maniltoa yang diamati dan warna putih dijumpai pada jenis-jenis Brownea, Cynometra, Saraca, dan A. nobilis. Warna daun pada setiap kelompok daun saputangan bervariasi, yaitu merah jambu pucat pada jenis $M$. grandiflora dan $M$. schefferi, hijau pupus ( $M$. plurijuga), merah jambu (M. lenticellata), serta hijau muda (M. polyandra). Semua jenis Brownea memiliki daun muda berwarna ungu kecokelatan bercorak hijau. Jenis-jenis Cynometra memiliki daun muda yang bervariasi, antara lain merah jambu (C. cauliflora dan C. mannii), putih kehijauan (C. minutiflora), putih susu (C. ramiflora). Marga Saraca memiliki dua variasi warna daun muda, yaitu kuning ( $S$. indica), dan ungu muda $(S$. thaipingensis). A. nobilis memiliki daun muda berwarna cokelat.

Selain warna daun, tangkai daun muda pada kelompok daun saputangan juga memiliki warna yang bervariasi. Variasi warna tersebut yaitu hijau (M. grandiflora, A. nobilis, C. minutiflora, C. ramiflora, serta semua jenis Brownea yang diamati), dan merah (M. polyandra, $C$. mannii, $C$. minutiflora, $S$. indica dan $S$. thaipingensis) (Gambar 4). 


\begin{abstract}
Variasi Fase Daun Saputangan Terbuka
Daun saputangan terbuka ditandai dengan adanya perubahan pada penampilan umum dan warna daun yang berbeda dari daun saputangan terlipat. Fase ini disebabkan oleh daun muda yang tumbuh melebar dan terbentuk dengan ukuran daun yang sempurna serta tekstur daun sudah menjadi kaku, sehingga helaian saputangan menjadi lebih jelas terlihat. Variasi warna daun saputangan terbuka terdiri atas warna hijau lumut yang ditunjukkan pada jenis $M$. grandiflora, $M$. polyandra, dan $M$. schefferi. Warna hijau keputihan ditemukan pada jenis $M$. lenticellata dan $S$. thaipingensis. Warna hijau pupus dijumpai pada jenis $C$. minutiflora. Warna hijau terang pada jenis $S$. indica dan $M$. plurijuga, serta warna hijau kecokelatan ditemukan pada C. cauliflora, C. ramiflora, C. mannii, dan semua jenis dari marga Brownea yang diamati (Gambar 5).
\end{abstract}

\title{
Berikut kunci determinasi jenis-jenis tumbuhan suku Caesalpiniaceae berdaun saputangan.
}

1a Kuncup dorman berperula, warna indumentum pada kuncup tumbuh cokelat, helaian dauna simetri ..... 2 2a Kuncup tumbuh bervariasi (melanset, melonjong, melonjong ujung runcing, melanset bagian tengah agak melebar), daun penumpu melanset Maniltoa 3a Tepi daun rata

\section{Fase Daun Dewasa}

Daun dewasa pada tumbuhan berdaun saputangan memiliki ciri pembeda berdasarkan bentuk daun, bentuk pangkal daun, bentuk ujung daun, tepi daun, simteri daun, panjang dan lebar ukuran daun, jumlah anak daun dalam daun majemuk, dan tekstur permukaan daun. Warna daun dewasa pada tumbuhan berdaun saputangan didominasi oleh warna hijau tua terang sampai hijau tua gelap. Bentuk daun asimetri ditunjukkan oleh marga Maniltoa, Brownea, dan Cynometra, sedangkan bentuk daun simetri ditunjukan oleh marga Saraca dan Amherstia. Keadaannya tidak diuraikan lebih lanjut, dikarenakan ciri-cirinya sudah umum dipertelakan dalam pustaka-pustaka yang memberikan deskripsi masing-masing jenis. (Gambar 6).

4a Kuncup daun tumbuh melanset bagian tengah agak melebar, kuncup daun tumbuh hijau lumut, pada fase daun saputangan muncul mula-mula putih kehijauan hingga kekuningan, jumlah daun dalam satu tangkai $2-3$ pasang M. polyandra

4b Kuncup daun tumbuh melonjong, kuncup daun tumbuh hijau kekuningan, pada fase daun saputangan muncul mula-mula putih tulang hingga putih kehijauan, jumlah daun dalam satu

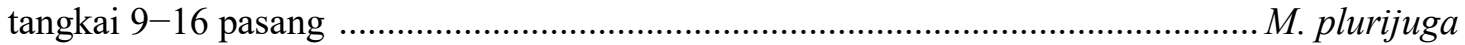

3b Tepi daun berombak 5

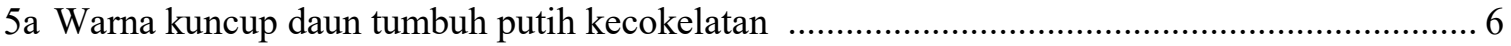
6a Pada fase daun saputangan muncul mula-mula putih hingga merah jambu pucat 6b Pada fase daun saputangan muncul mula-mula merah jambu pucat hingga merah jambu...... M. schefferi

$5 b$ Kuncup daun tumbuh putih kehijauan, daun pada fase daun saputangan muncul merah jambu M. lenticellata

$2 \mathrm{~b}$ Kuncup daun tumbuh melancor 7

7a Tipe penggulungan daun muda menggulung-gulung sampai tergulung masuk, tipe indumentum pada kuncup tumbuh berbulu balig, daun penumpu membenang Brownea 8a Daun pada fase daun saputangan muncul mula-mula ungu tua dengan corak hijau lalu

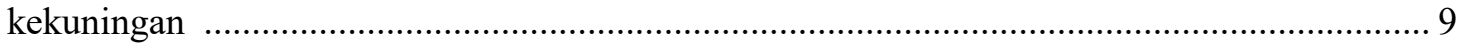

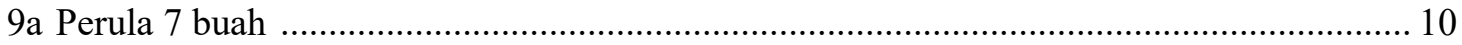

10a Rambut-rambut kasar di ujung rachis $0.7-1.5 \mathrm{~cm}$, helaian daun membundar telur, melanset, melanset sungsang ..................................................................... . capitella

10b Rambut-rambut kasar di ujung rachis $10-15 \mathrm{~cm}$, helaian daun membundar telur, memanjang, menjorong, melanset sungsang

B. ariza

9b Perula 10 buah, jumlah helai daun 72 buah .................................................. B. grandiceps

8 b Daun pada fase daun saputangan muncul mula-mula merah jambu pucat dengan corak hijau lalu kekuningan

B. racemosa

$7 \mathrm{~b}$ Tipe penggulungan daun muda menggulung-gulung, tipe indumentum pada kuncup daun tumbuh 
berbulu sikat, daun penumpu memita

Cynometra

11a Jumlah daun dalam satu tangkai 2-3 pasang 12

12a Jumlah tangkai daun dalam satu kali pemoposan 4-6 tangkai, jumlah daun dalam satu tangkai 2 pasang, jumlah helaian anak daun12-24 helai. .13

13a Daun pada fase daun saputangan terlipat tampak putih kekuningan .......C. ramiflora

13b Daun pada fase daun saputangan terlipat tampak putih kemerahan .....C. minutiflora

12b Jumlah tangkai daun dalam satu kali pemoposan 6-8 tangkai, jumlah daun dalam satu tangkai 3 pasang, jumlah helain anak daun 48 helai C. mannii

11b Jumlah daun dalam satu tangkai 1 pasang, jumlah anak daundalam 1 fase pemoposan 8 helai C. cauliflora

$1 \mathrm{~b}$ Kuncup dorman tidak berperula, tipe pelipatan daun dalam kuncup daun tumbuh melingkar, helaian daun simetris, daun penumpu melanset

14a Kuncup daun tumbuh melanset, tipe indumentum pada kuncup dan daun muda memisai ...... Saraca

15a Kuncup daun tumbuh merah marun, daun pada fase daun saputanga terlipat keseluruhan tampak kuning kehijauan, ujung daun menumpul S. indica

15b Kuncup daun tumbuh hijau, daun pada fase daun saputangan terlipat keseluruhan tampak ungu muda, ujung daun meruncing S. thaipingiensis

14b Kuncup daun tumbuh memanjang, ujung daun bertugi, tipe indumentum pada tangkai daun mengewol Amherstia

16 Daun pada fase daun saputangan terlipat keseluruhan tampak cokelat, permukaan adaksial daun kasap A. nobilis

\section{SIMPULAN}

Tumbuhan suku Caesalpiniaceae berdaun saputangan16 jenis ini dapat dibedakan berdasarkan ciri diagnostik yang teramati pada setiap variasi fase proses pemoposan daun. Ciri diagnostik ini meliputi ada atau tidak adanya kuncup dorman, keberadaan perula, bentuk kuncup daun dorman, bentuk kuncup daun tumbuh, tipe indumentum kuncup daun tumbuh, variasi bentuk daun selama proses terjadinya pemoposan, jumlah daun, ukuran daun, dan warna daun saat pemoposan.

\section{UCAPAN TERIMAKASIH}

Ucapan terima kasih disampaikan kepada Prof. Dr. Mien A. Rifai untuk saran dan pengarahan selama melaksanakan penelitian. Terima kasih penulis juga sampaikan kepada Herbarium Bo-goriense (BO) yang telah memberikan kesempatan kepada penulis untuk memeriksa spesimen herbarium untuk 5 marga kelompok tumbuhan ber-daun saputangan. Terima kasih juga disampaikan kepada badan pengelola Kebun Raya Bogor dan teman-teman yang telah membantu dan mem-berikan semangat kepada penulis pertama.

\section{DAFTAR PUSTAKA}

Ash A, Ellis B, Hickey LJ, Johnson K, Wilf P \& Wing S. 1999. Manual of Leaf Architecture. Washington DC (US): Smithsonian Institution.

Backer CA \& Bakhuizen van den Brink RC. 1965. Flora of Java. 2. Groningen (NL): Noordhoff.

Balgooy MMJ van. 1997. Malesian Seed Plants: Spot-Characters. Leiden (NL): Rijksherbarium.

Bell AD. 1991. Plant Form: An Illustrated Guide to Flowering Plant Morphology. New York (US): Oxford Univ Pr.

Budiman M. 1978. Saputangan dari Sri Langka (Saraca indica L.): Kemungkinan sebagai tanaman tepi jalan. Bul Kbn Raya. 3 (4): 121-123.

Cullen J. 1978. A preliminary survey of ptyxis (vernation) in the angiosperms. Notes Royal Botanic Garden, Edinburgh 37: 161-214.

Harris JG \& Harris MW. 2001. Plant Identification Terminology: An Illustrated Glossary. 2 editions. United States (US): Spring Lake Publishing.

Hickey LJ. 1973. Classification of the architecture of dicotyledonous leaves. Am J Bot. 60(1): $17-33$. 
Nicolini E, Beauchene J, de la Vallee B, Ruelle J, Mangenet $T$ \& Heuret P. 2012. Dating branch growth units in a tropical tree using morphological and anatomical markers: The case of Parkia velutina Benoist (Mimosoideae). Anna of Forest Sci. 69: 543-555.

Putri EK \& Chikmawati T. 2015. Leaf flushing as taxonomic evidence of some Diospyros species. Floribunda. 5(2): 31-47.

Radford AE. 1986. Fundamentals of Plant Systematics. New York (US): Harper \& Row.
Rahmania F \& Munandar A. 2005. Studi fenologi dan determinasi arsitektur pohon hias. JLI. 1 (1): 14-20.

Rifai MA \& Puryadi D. 2008. Glosarium Biologi. Jakarta (ID): Pusat Bahasa Departemen Pendidikan Nasional.

Uji T. 1980. Pohon saputangan (Maniltoa gemmipara Scheff. ex Back.) sebagai tanaman hias dan peneduh. Bul Kbn Raya. 4 (5): 161-164. 

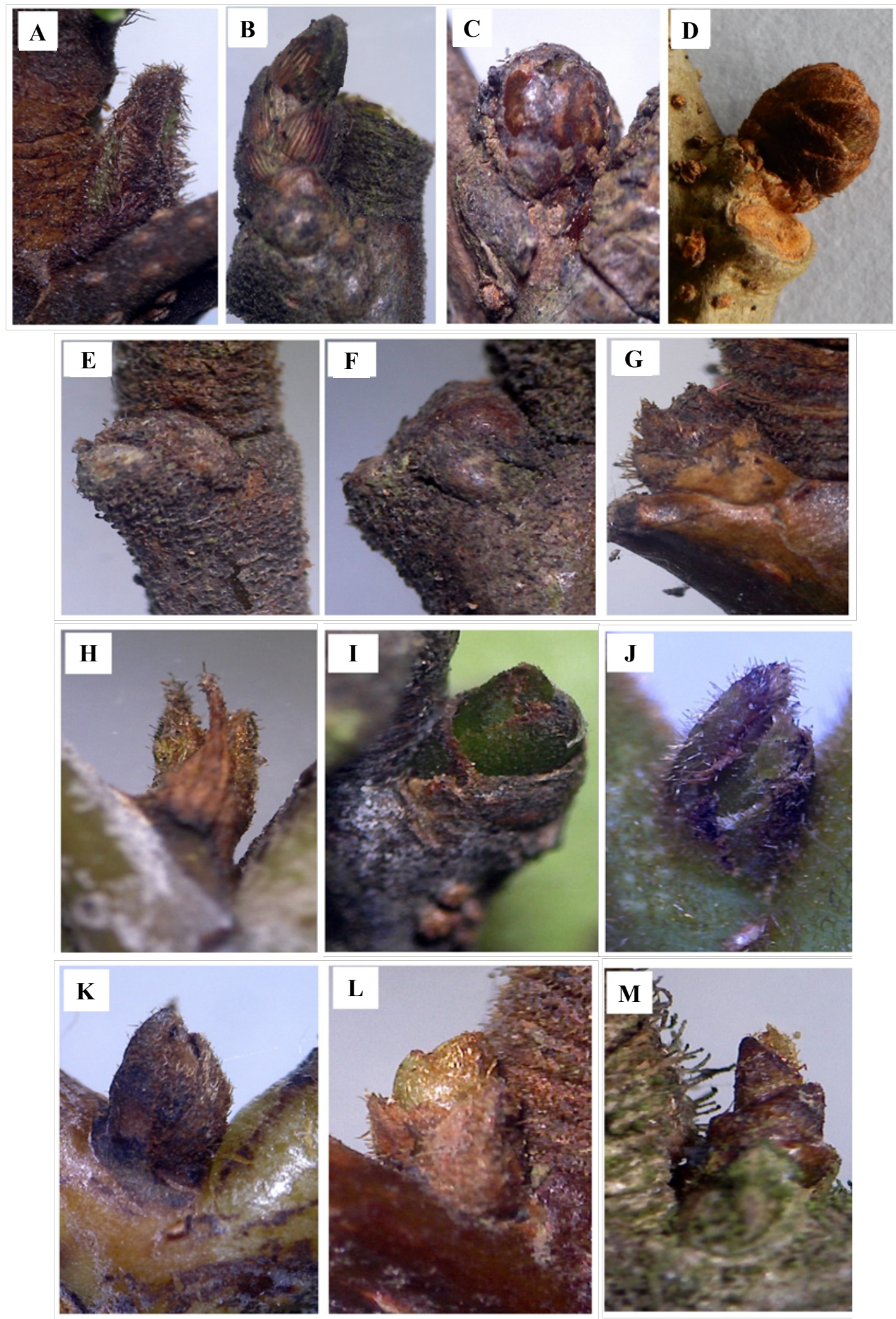

Gambar 1. Kuncup daun dorman: A. M. grandiflora; B. M. lenticellata; C. M. plurijuga; D. M. polyandra; E. M. schefferi; F. B. ariza; G. B. capitella; H. B. grandiceps; I. B. racemosa; J. C. cauliflora; K. C. mannii; L. C. minutiflora; M. C. ramiflora. 

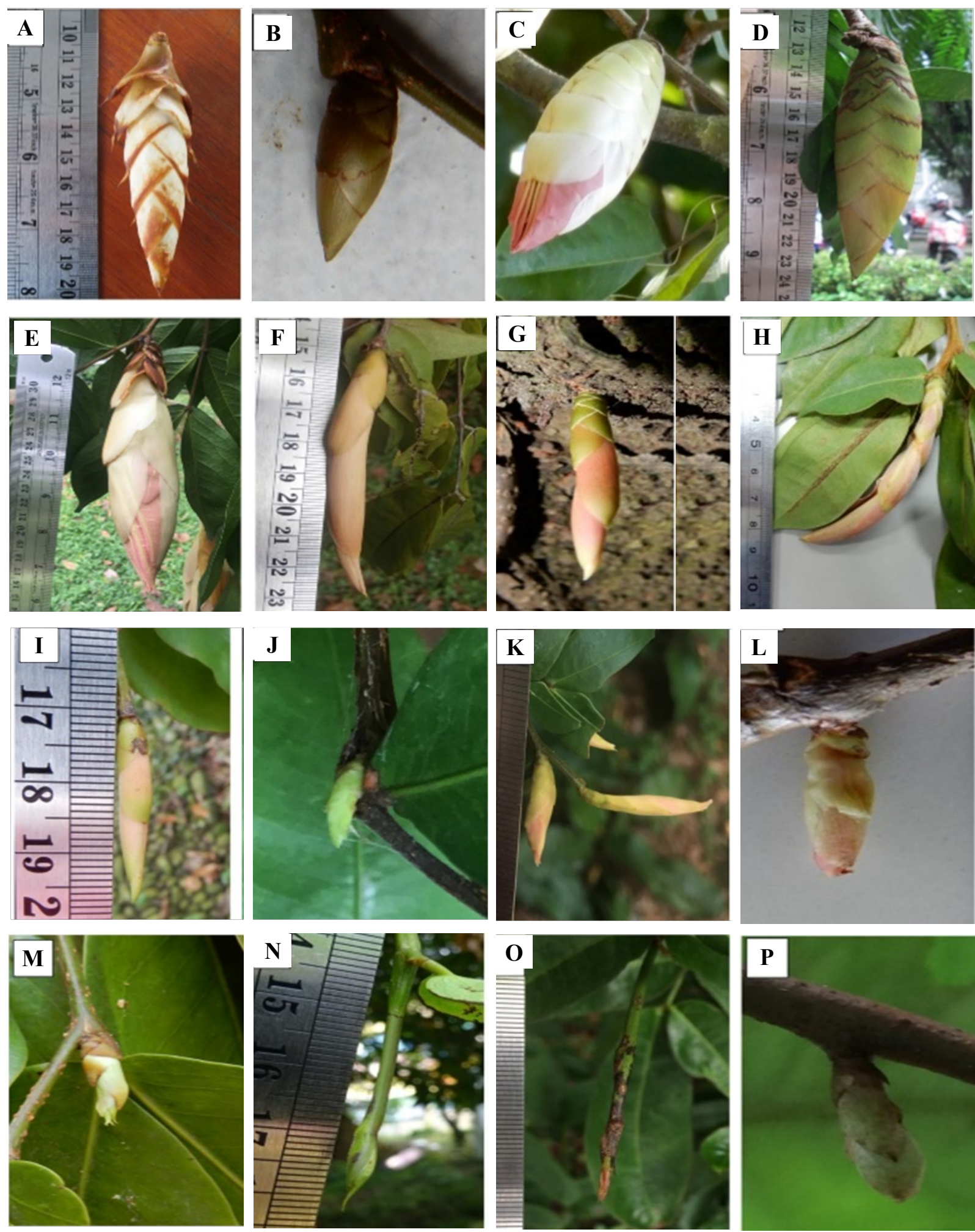

Gambar 2. Kuncup daun tumbuh: A. M. grandiflora; B. M. polyandra; C. M. lenticellata; D. M. plurijuga; E. M. schefferi; F. B. ariza; G. B. capitella; H. B. grandiceps; I. B. racemosa; J. C. minutiflora; K. C.mannii; L. C. cauliflora; M. C. ramiflora; N. S. thaipingensis; O. S. indica; P. A. nobilis 

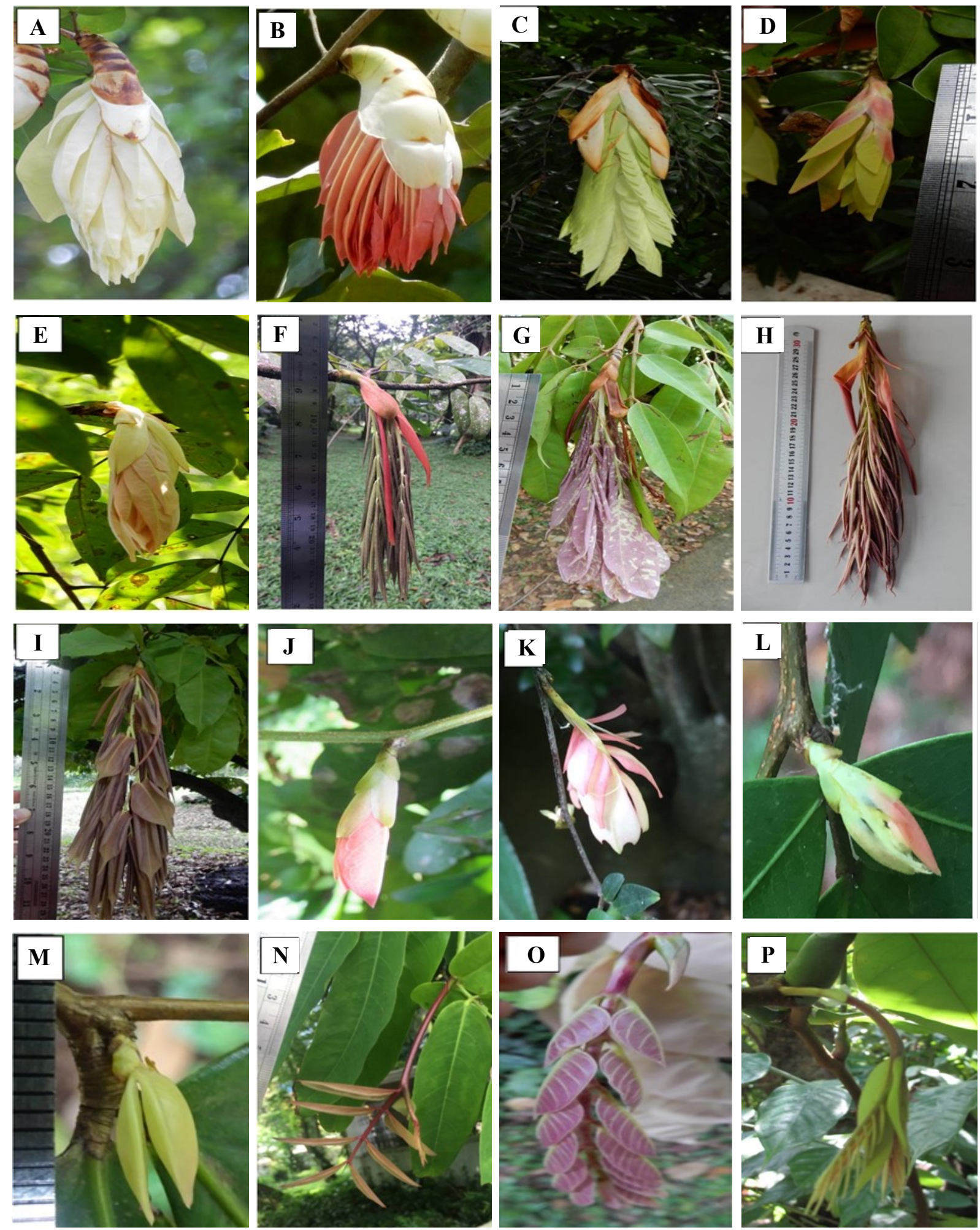

Gambar 3. Daun saputangan muncul: A. M. grandiflora; B. M. lenticellata; C. M. plurijuga; D. M. polyandra; E. M. schefferi; F. B. ariza; G. B. capitella; H. B. grandiceps; I. B. racemosa; J. C. cauliflora; K. C. mannii; L. C. minutiflora; M. C. ramiflora; N. S. indica; O. S. thaipingensis; P. A. nobilis 

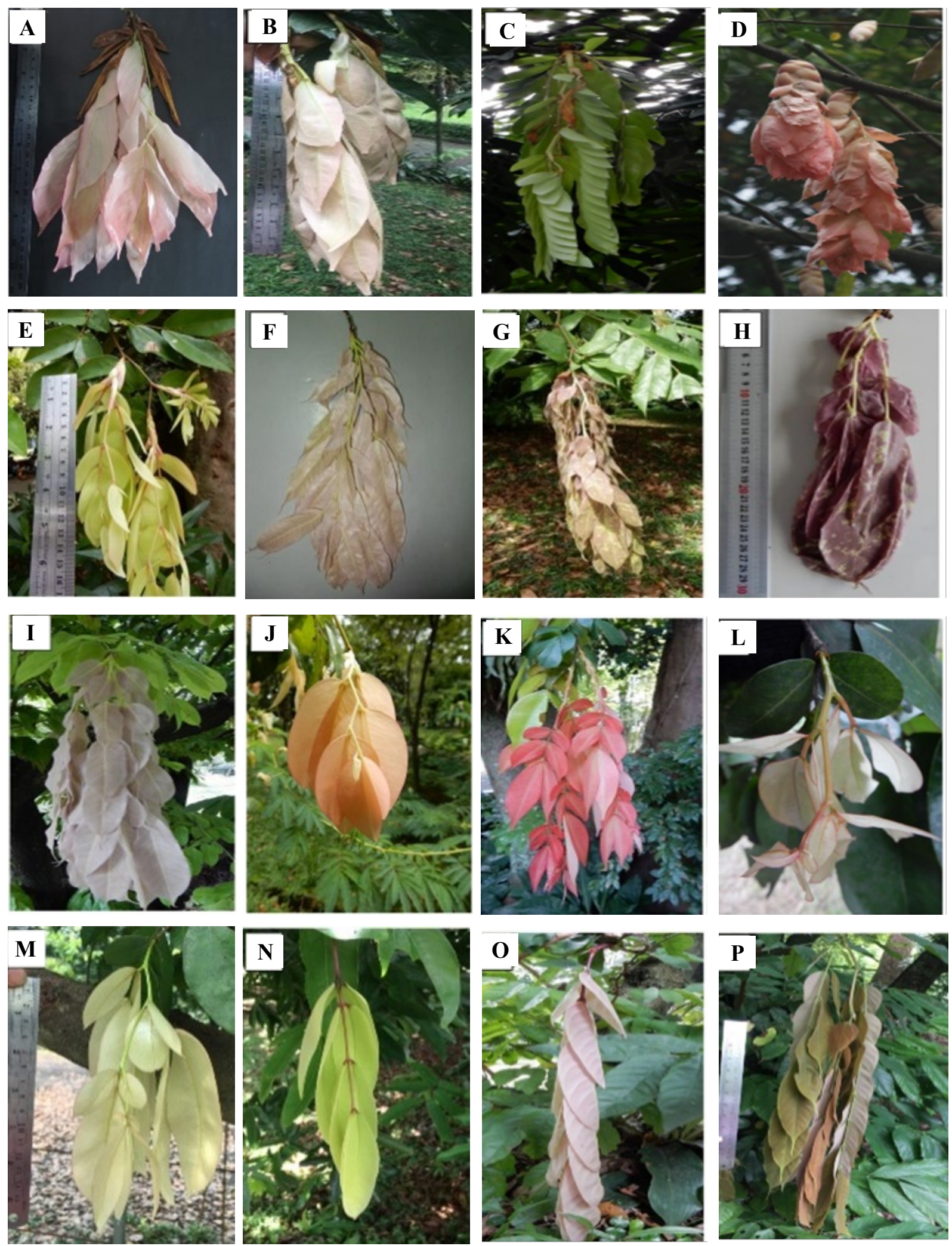

Gambar 4. Daun saputangan terlipat: A. M. grandiflora; B. M. schefferi; C. M. plurijuga; D. M. lenticellata; E. M. polyandra; F. B. ariza; G. B. capitella; H. B. grandiceps; I. B. racemosa; J. C. cauliflora; K. C. mannii; L. C. minutiflora; M. C. ramiflora; N. S. indica; O. S. thaipingensis; P. A. nobilis 

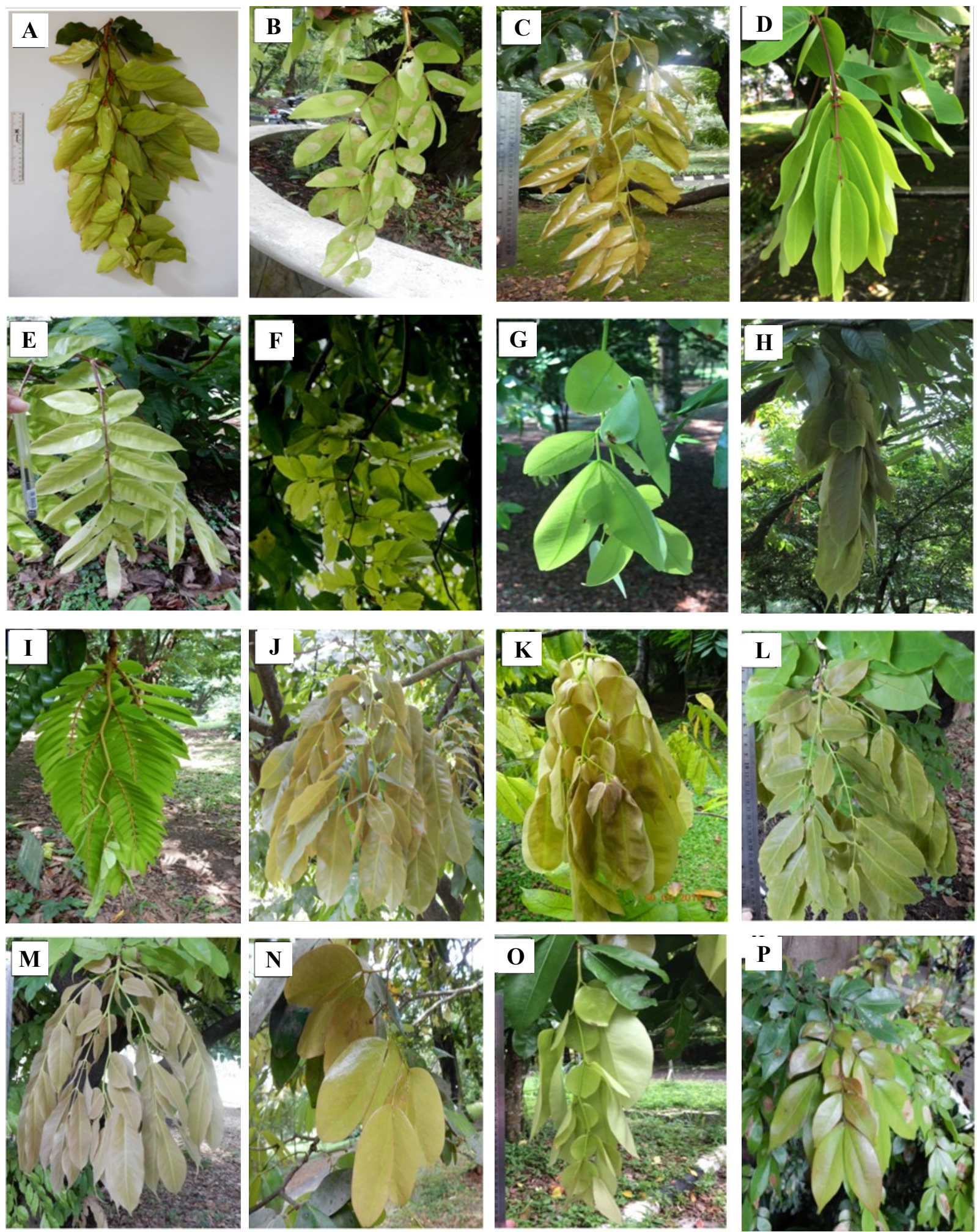

Gambar 5. Daun saputangan terbuka: A. M. grandiflora; B. M. polyandra; C. M. schefferi; D. S. indica; E. S. thaipingensis; F. M. lenticellata; G. C. minutiflora; H. A. nobilis; I. M. plurijuga; J. B. ariza; K. B. capitella; L. B. grandiceps; M. B. racemosa; N. C. cauliflora; O. C. ramiflora; P. C. mannii 

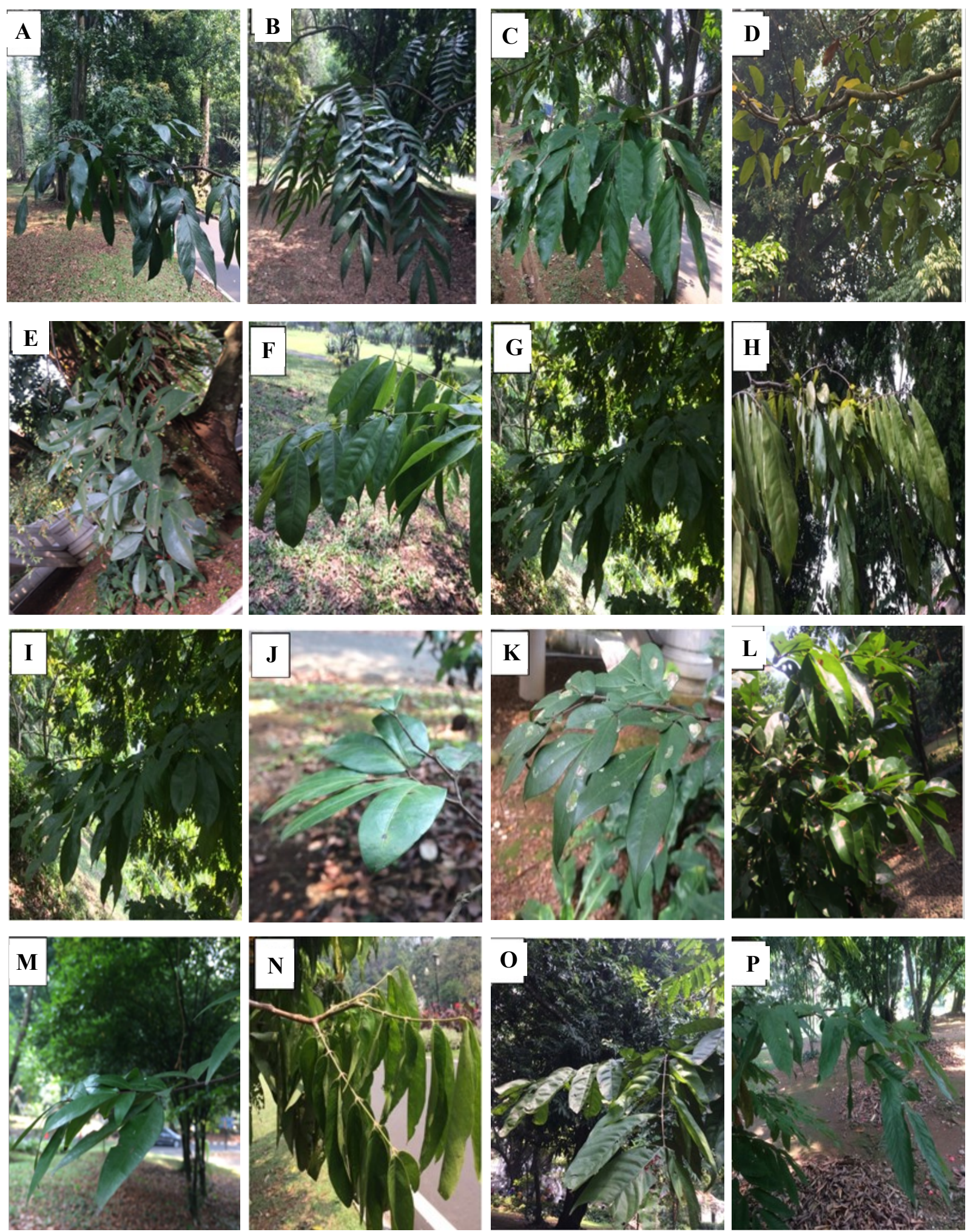

Gambar 6. Daun saputangan dewasa: A. M. grandiflora; B. M. lenticellata; C. M. plurijuga; D. M. schefferi; E. M. polyandra; F. B. ariza; G. B. capitella; H. B. grandiceps; I. B.racemosa; J. C. caulifora; K. C. manii; L. C. minutiflora; M. C. ramiflora; N. S. indica; O.S. thaipingensis; P. A. nobilis 